\title{
Brazilian Policy and the Creation of a Regional Security Complex in the South Atlantic: Pax Brasiliana?
}

\author{
Beatriz Rodrigues Bessa Mattos* \\ Francisco Eduardo Lemos de Matos ${ }^{* *}$ \\ Kai Michael Kenkel ${ }^{* * *}$
}

\begin{abstract}
Over the past five years, the South Atlantic region has become a central element of Brazilian security policy, with Brazil actively supporting the notion of a trans-oceanic security consciousness involving African littoral states. It has invested in diplomatic initiatives such as the Zone of Peace and Cooperation of the South Atlantic (ZPCSA, or ZOPACAS), and extensive military co-operation with West African states such as São Tomé e Príncipe, Namibia and Cape Verde. Its internal security and defence policy documents have repeatedly been updated to reflect this dimension, and now provide the foundation for advancing these initiatives. This policy thrust is directed at securing Brazil's offshore oil assets, and limiting the influence of what it has termed 'extra-regional powers' such as the P-5. This article highlights these initiatives and reviews the prospects for this policy by examining the plausibility of the South Atlantic region as a regional security complex in the sense coined by Buzan and Wæver. The analysis is based on the role of geographical and linguistic proximity in international relations, and the impact of multilateral bodies on building support for a regional approach to security governance.
\end{abstract}

Keywords: South Atlantic; Regional Security Complex; Security Communities; South-South Cooperation; South Atlantic Peace; Co-operation Zone.

\section{Introduction}

Some $26.6 \%$ of Brazil's population is concentrated in the country's immediate coastal areas (IBGE 2011). Some $95 \%$ of its international trade transits the Atlantic, and more than $90 \%$ of the oil produced in Brazil comes from offshore platforms (Penna Filho 2015). Brazil's maritime borders are 7367 kilometers long, make up 32\% of all its borders, and touch upon a territorial sea spanning 3.54 million square kilometres. Given these dimensions,

\footnotetext{
* $\quad$ Pontifical Catholic University of Rio de Janeiro (PUC-Rio), Rio de Janeiro-RJ, Brazil; beatrizrbm@gmail.com.

** Pontifical Catholic University of Rio de Janeiro (PUC-Rio), Rio de Janeiro-RJ, Brazil; edumatos@hotmail.com.

*** Pontifical Catholic University of Rio de Janeiro (PUC-Rio), Rio de Janeiro-RJ, Brazil; kenkel@puc-rio.br.
} 
the importance to Brazil of the sea and therefore the South Atlantic Ocean - defined here as the entire Atlantic Ocean south of the Equator, bounded by the coastlines of South America, Africa and Antarctica - is beyond doubt. These few facts underscore the extent of Brazil's interest in the region, pointing to the need to retrace the historical development of the country and the political interpretation of the ocean's significance by its Ministries of Defence and Foreign Affairs, notably with respect to current plans to foster the emergence of a common South Atlantic identity.

In this framework, and proceeding from the notion of the 'Blue Amazon' - a metaphor for Brazil's maritime zone of control which latches onto a land-based narrative of Brazilian greatness - as well as co-operation initiatives and technical, military and economic discourses, this article seeks to establish why fostering a South Atlantic security complex benefits Brazilian foreign and security policy. We seek to show how and why the region became a showcase for the principles underlying Brazilian security policy, and consequently to understand, from a critical perspective, how the Brazilian government has worked to create a common identity in the South Atlantic region, akin to the emergence of a regional security complex (RSC) as defined in theoretical approaches to international security. Our main argument is that, in reinforcing such a common consciousness, grounded on shared goals and values, and linking it to the perception of common threats to participating states, Brazil is staking its own claim to leadership in the region by, inter alia, preventing major powers from projecting their own aspirations to a global presence onto its South Atlantic backyard.

\section{Regional security complex theory}

Regional security complex (RSC) theory was developed by Barry Buzan and Ole Wæver, and first advanced in 1983. Buzan and his colleagues initially defined RSCs as 'a set of units whose major processes of securitization, desecuritization, or both, are so interlinked that their security problems cannot reasonably be analyzed or resolved apart from one another' (Buzan, Wæver and de Wilde 1998: 201). States were taken be their main constituent units. In 2003, however, they broadened their definition of RSCs, stating that they were 'regions as seen through the lens of security' (Buzan and Wæver 2003: 44) and could not be defined merely in geographic terms, since they were contingent upon the interactive security practices of their members. As pointed out by Frazier and Stewart-Ingersoll, 'RSCs allow us to focus upon groupings of states whose actions dominate the security considerations of other member states' (Frazier, Stewart-Ingersoll 2010: 733).

Buzan and Wæver (2003) have argued that the dynamics of RSCs are situated along a continuum, within three different patterns of interaction: conflictual relations, security regime, and security community. When conflictual relations are the pattern of an RSC, it is marked by balance-of-power dynamics, alliance formation and securitisation processes among its members (Buzan and Wæver 2002: 47). Security regimes, according to this conception, emerge from the efforts of a group of states that seeks to manage disputes and avoid war (Buzan 1991). In a security regime, actors' interests are not necessarily convergent, and such a regime can flourish in an environment where 'the use of force is 
inhibited by the existence of a balance of power and mutual deterrence situation' (Acharya 2009: 19). Security communities, by contrast, are regions whose societies do not feel threatened by the use of force among each other, since mutual trust and a shared identity enable expectations of peaceful change (Adler and Barnett 1998). This 'we-feeling', which characterises security communities, allows for a de-escalating desecuritisation process in which regional actors no longer see each other as threats (Buzan and Wæver 2003: 53, 55), creating expectations of peaceful change and accommodation.

Given these variations, the RSC model embodies not only material elements - such as anarchy, polarity among its members, and geographical proximity - but also ideational ones (Buzan and Wæver 2003). This last variable is responsible for endowing this approach with an intersubjective character, differentiating it from materialist theories, which assume that 'state interests are shaped by material forces and concerns, such as power and wealth' (Acharya 2009: 28).

Although recognising the relevance of material elements, Buzan and Wæver (2003) highlight the importance of ideational aspects such as shared ideas, meanings, identities, and social and historical contexts in understanding the consolidation of co-operative ties, or adversarial relations, among actors. The interdependent character of RSCs makes their members more prone to interaction, and these social relations affect the way they see each other. Thus RSCs are not merely the sum of their parts, but rather function as structures capable of modifying patterns of behaviour among their members, since they are capable of shaping interests, values, meanings and identities (Buzan and Wæver 2003; Frazier and Stewart-Ingersoll 2010).

Considering Buzan and Wæver's framework, RSCs can be classified in terms of three distinctive criteria: polarity (unipolar or multipolar); forms of interaction (amity and enmity); and the role of their members in the international system. As regards the lastnamed criterion, the authors identify two major types of RSCs: standard and centred (Buzan and Wæver 2003: 53, 54). A standard RSC shares characteristics with the Westphalian order, meaning that it has an anarchical structure and does not include an overarching power, although it can be penetrated by an external power. On the other hand, a centred RSC obtains when a great or superpower is present in the region, usually dominates it, and prevents the emergence of other regional powers. Centred RSCs also include regions integrated by institutions other than a great power or superpower (Buzan and Wæver 2003: 55, 56).

As demonstrated by Abdenur and Souza Neto (2014b), the consolidation of RSCs is frequently led by one or more states with specific interests, labelled as region-builders. In this sense, the South Atlantic has occupied an important position on the Brazilian security agenda for several years, especially following recent finds of off-shore oil reserves, thereby heightening the interest of global powers in this region.

According to Frazier and Stewart-Ingersoll (2010), the possession of material capabilities is insufficient to make a state behave as a regional power; there must be an ideational motivation as well. Hence, Brazil's interest in the creation of a South Atlantic RSC cannot be explained only by its dominant position among South Atlantic states. It accordingly 
becomes necessary to analyse the social interaction among states in order to explain why some become regional powers by developing and maintaining RSCs.

In this theoretical context, we analyse the historical, political and geopolitical factors that have prompted Brazil to promote a South Atlantic RSC by strengthening co-operation and amicable relations with relevant states, and seeking to build a shared consciousness among them. In doing so, we recognise Buzan and Wæver's emphasis on the role of securitisation in the face of real or perceived external threats in the process of identitybuilding. The construction of a common identity is typically based on the idea of 'us versus them', contributing to the creation of a regional security strategy and the emergence of a shared consciousness about and among the region in question. According to Frazier and Stewart-Ingersoll (2010: 742), protection against external threats can also result in gains in influence over members, making it easier for a regional power to play a leadership role.

Against this background, this article focuses on Brazil's efforts to play such a power role and to construct a shared consciousness in the South Atlantic, by emphasising and promoting the existence of common ideas, values and interests, and especially by building a perception of common threats to the region.

\section{The origins of the South Atlantic RSC: the Zone of Peace and Cooperation of the South Atlantic (ZPCSA)}

Naval co-operation among South Atlantic states began in 1986 when, in pursuit of a Brazilian initiative, the UN General Assembly approved the establishment of the ZPCSA. ${ }^{1}$ Encompassing 24 nations, three South American and 21 African, this multilateral organisation was created to preserve the independence, sovereignty and territorial integrity of states in the region, assuring the South Atlantic as a pacific, demilitarized zone, free from nuclear weapons and the presence of foreign powers (UN 1986). Its formation was suggested at the end of the Cold War and soon after the 1982 Falkland/Malvinas conflict, sparking the hope of reorganising security in the region without interference from external global powers. There was a perceived need to increase co-operation and dialogue, with the aim of preserving regional states' interests and sovereignty.

This initiative was the first significant element in Brazilian security policy towards the South Atlantic. The primary objective of the ZPCSA is to make the South Atlantic a nuclear-weapons-free zone; however, the Brazilian position has been influenced by even broader goals. The Malvinas/Falklands conflict showed the need to prevent the militarisation of the South Atlantic, and the ZPCSA was seen as a mechanism for achieving this objective. Brazil, which had always largely conducted its trade relations by means of maritime routes, had also become aware of the immense economic and strategic importance of the South Atlantic. Thus, the ZPCSA was also intended to intensify Brazil's trade relations with African countries (Penna Filho 2015).

The end of the Cold War resulted in a decrease of ZPCSA activities; however, the weakening of this multilateral organisation did not end co-operation between Brazil and other states in the region. This co-operation has been strengthened in recent years by the growing strategic importance of the South Atlantic to Brazil, despite variations in the 
intensity and breadth of Brazilian co-operation measures in accordance with domestic political and economic conditions.

Therefore, it is possible to claim that the conceptualisation of security policy for the South Atlantic, which confirms a putative Pax Brasiliana, first began with the Brazilian initiative to create the ZPCSA in 1986. This initiative set the stage for the important role of the South Atlantic region in Brazilian military thinking. The second point worth noting derives from the change in foreign policy introduced in 2003 by the Lula da Silva administration, which gave increased importance to the strengthening of relations with African countries. This move filled a political space that had been relegated to the background. The third noteworthy point is the discovery in 2007 of oil reserves in the coastal pre-salt (Pré-Sal) basins ${ }^{2}$ as well as vast reserves of other minerals in the marine region that subsequently became known as the 'Blue Amazon.' ${ }^{3}$ In this context, we note rising economic concerns about the exploitation of natural resources. These three moments are key to understanding the ensuing formulation of Brazilian defence policy.

Given the South Atlantic's relevance to Brazilian interests, the ZPCSA has received considerable attention in the country's foreign policy in recent years. Given its potential to act as an engine of co-operation with Africa, the ZPCSA could produce a vast economic development complex that would allow the integration of the region and the construction of common values that do not necessarily already exist. While the ZPCSA was created to ward off external threats, this particular dynamic could facilitate the formation of common values, and ultimately a South Atlantic identity.

\section{The role of the South Atlantic in Brazil's relations with African littoral states}

Brazil's attention to Africa during the past decade is aligned with a significant shift in foreign policy under the Lula administration. This does not ignore the foreign policy gains under the previous governments of Fernando Henrique Cardoso; however, perhaps the most significant divergence involves the importance of Africa in Brazil's global project. Both the Lula and Dilma Rousseff governments fostered a synergy between foreign policy and defence policy by looking to Africa, and acknowledging that the South Atlantic region had profound strategic importance for Brazil. This was reflected inter alia in the composition of the 2013 ZPCSA meeting in Montevideo, which was the first to include active foreign affairs and defence ministers.

Early in his administration, Lula began to reach out towards Africa, attempting to resuscitate the historical ties between the continent and Brazil, and emphasising a shared past that binds them together and reaffirms them as protagonists of a common history. These ideas planted the seed of a common identity in the South Atlantic region. By redeeming a shared past of suffering and exploitation, Lula's policies were meant to draw Brazil and Africa closer together, and create a common identity.

However, the Africa policy was based on a paradigm that placed the continent in an earlier spatio-temporal economic and social locus than Brazil, an imagined earlier stage of evolution. From Brazil, West African countries could 'learn' how to become nation-states, 
based on the experience of another state with a common history of exploitation. This framework places Africa in a period that Brazil has surpassed. This perspective highlights the Brazil's perceived role in the construction of a South Atlantic identity: that of a socially, economically and technologically more advanced nation sharing its expertise with underdeveloped counterparts - rather like North-South interactions during the post-colonial period. Therefore, there is nothing naive in Brazil's new approach to Africa. On the contrary, it seeks to enter this dialogue from a position of superiority, creating ties and aiming to increase its area of influence.

In 2007, Brazil discovered major oil reserves in a marine area stretching more than 800 kilometres from the Brazilian coast, partly located in its Exclusive Economic Zone (EEZ). These Pré-Sal reserves occupied the headlines of Brazilian and international newspapers, raising the possibility that Brazil could become self-sufficient in oil production. Indeed, the country, which is dependent on oil for its energy needs, rated the Pré-Sal as fundamental to its overall national development. Control of the continental shelf and the South Atlantic became objects of national concern, with the South Atlantic region once again being regarded as strategic for Brazilian development.

A few years earlier - in 2004 - Brazil, which already believed in the existence of those natural resources, submitted a request for extension of its jurisdiction over the continental shelf to the UN, under Article 76 of the UN Convention on the Law of the Sea (UNCLOS). This would increase the area under Brazilian jurisdiction by about 950000 square kilometres, extend the EEZ by 200 miles, and incorporate another 150 miles beyond it (Paim 2014). The total marine area that would fall under Brazilian control, for the purposes of exploration and the exploitation of its living and non-living resources, would exceed 4.48 million square kilometres, equal to almost half of Brazil's vast land territory. Brazil managed to obtain partial fulfillment of its request. There is still a case under way for the release of more than 200000 square kilometres of the original request. The area is believed to harbour many resources besides oil, including gravel, clay, natural gas, gold, platinum, diamond, tin, iron, nickel, copper, cobalt and phosphorus (Paim 2014).

The 'Blue Amazon' concept drew on the recognised importance of the Amazon region in terms of natural resources. Its clear purpose is to raise awareness of the significance of the Pré-Sal reserves, other resources in the areas, and maritime commercial routes. In other words, it serves to highlight the importance of the South Atlantic region. The term reverberates in the patriotic imaginary, since it retrieves the greatness embedded in the constitutive idea of the Brazilian nation, which projects it as a country of the future.

Exaltation of the Amazon is not only a Brazilian claim; the importance assigned to the region is also reproduced at the international level. Given this, the region's importance in Brazilian political and strategic thinking should receive greater attention. The notion of the Blue Amazon reflects the fate of being great, projects itself as an engine of development, and contributes to the country's desire to be understood as a country of the future. The Blue Amazon has become a flagship of Brazilian defence policy and foreign policy, and underlines the importance of the South Atlantic region. The following sections highlight Brazilian efforts to build a South Atlantic consciousness outside its borders through 
different strategies, including official documents and discourses, domestic policies, and military co-operation in the naval sector.

\section{Brazilian policy for the South Atlantic: official documents and domestic policies}

Brazilian efforts to create a South Atlantic identity are reflected in various official documents, notably the 2011 White Paper on National Defence (Livro Branco de Defesa Nacional, or LBDN), the National Defence Strategy (Estratégia Nacional de Defesa, or END), and the National Defence Policy (Politica Nacional de Defesa, or PND), as well as official pronouncements. The White Paper is a leading example as it contains clear references to this regional identity, noting, inter alia, that: 'the South Atlantic has a historical identity and its own characteristics and profile'4 (Presidency of Brazil 2012: 36). This document highlights the importance of the South Atlantic to the strengthening of historical ties between Brazil and African nations, as revealed by the following extract: 'The South Atlantic brings together Brazil and its neighbours in Africa, which strongly influenced the creation of the Brazilian Nation' (Presidency of Brazil 2012: 52).

Brazilian representatives also support these ties in official pronouncements. During the Seventh Ministerial Meeting of the ZPCSA in 2013, Antonio Patriota, then Brazilian minister of foreign affairs, stated: 'This meeting proves again the commitment of African and South American countries to a South Atlantic identity. An identity which is reinforced by the changes seen in international context [...] The South Atlantic is a bridge between brother continents' (Ministry of Foreign Affairs of Brazil 2013b).

This notion of a common identity is based on exclusionary practices, created from antagonistic ideas of 'others versus us' that contribute to building up a common security strategy, and warding off external power penetration in the region. This is evident from speeches by the Brazilian minister of defense, Nelson Jobim, in response to the Atlantic Basin Initiative, a proposal aimed at unifying North and South Atlantic countries:

I cannot see well any way of approaching North Atlantic and South Atlantic, a vital geostrategic area to Brazil. The security concerns related to these different halves of the Atlantic Ocean are clearly apart. [...] These issues deserve different answers - more efficient and fair as less involved States and organizations are from outside the region (Jobim 2010).

Brazilian efforts to foster a South Atlantic identity are not only related to foreign policy. Internally, Brazil has been trying to embed a maritime consciousness in its civil society imaginary (Abdenur and Souza Neto 2014b). In an attempt to raise awareness of the ocean's importance, especially among children and youths, the Education Ministry and the Brazilian Navy released educational books around this theme, entitled The Sea in Brazilian Geographic Space and The Ocean's Importance in Brazilian History. These books were distributed to teachers, and their main concepts were included in the educational curriculum. 
The frequent references - in speeches, official documents, and even educational material - to Brazilian jurisdictional waters as the 'Blue Amazon' attained a symbolic dimension, reflecting the strategic importance given by the Brazilian state to its marine resources. Within the military ambit, the guidelines for Brazil's security policy are set out in the National Defence Strategy of 2008. This document sets out the domestic and international factors and circumstances that determine the country's national defence objectives, and the best means of achieving them (Presidency of Brazil 2008: 42). The South Atlantic features prominently in this strategy. It devotes much of its attention to the recognition of the region as a strategic entity, and points out the need to build a regional identity, while seeking to achieve national objectives (Presidency of Brazil 2008: 42).

The document deals with the possibilities of armed conflict in the South Atlantic region, and the restructuring of military forces to strengthen the Brazilian presence (Presidency of the Republic of Brazil 2008: 48-9). It should be noted that the development of the Brazilian state is closely linked to a projection of power and the development of a national defence policy, with maritime territorial expansion added to the consolidation of Amazon borders. Therefore, the development-defence nexus is a central element of Brazilian statecraft.

In the 2012 version of the Brazilian White Paper on National Defence, derived from the END, Brazil reaffirms its area of political interest and concern as South America, the South Atlantic and the West Coast of Africa (Presidency of Brazil 2012: 2). Inter alia, it states:

The first segment physically and economically connects the country to the South Atlantic. Within this region we find the most populous band of territory, and the country's major ports - Santos, Rio de Janeiro, Paranaguá, Recife (Sauípe), Salvador and Vitória -, through which flow the majority of Brazil's foreign trade [...] The maritime segment is vital to the political and economic links to the neighbouring states of the Southern Cone. Eastward projection leads us to the states of West Africa, where we highlight the Cape Route, an important strategic communication route between Africa, Asia, and the Northern Hemisphere (Presidency of Brazil 2012: 16).

The first point to note is the focus placed upon coastal areas in Brazilian strategic thinking; while the sparsely populated Amazon is an important source of resources, Brazil's population, and thus the core of its geostrategic thinking, are concentrated on its coastline. The occupation of the coastal zone, as illustrated in the White Paper, underlines this. In this view, Brazil's foreign economic policy has always been focused on maritime routes, and contemporary concerns date from well before the Pré-Sal discoveries. The preoccupation with the South Atlantic has deeper roots in the development of Brazilian society, as well as the Brazilian state and its foreign policy; it did not only emerge from the above documents, or from foreign policy under the Lula administration, but developed, and was strengthened, over time. 
The White Paper concludes that Brazil's dependence on maritime commercial traffic constitutes a huge defence challenge. However, attention is not restricted to the maritime trade routes; the exploitation of living and non-living resources also becomes a concern for defense policy. In this sense, the first clear objective, referring to the South Atlantic, is the Brazilian claim to jurisdictional control over more than 965000 square kilometres of marine territory (Presidency of Brazil 2012: 17).

This region holds immense oil reserves, recognised in the White Paper as a potential engine of development, thus necessitating the monitoring and control of maritime traffic (Presidency of Brazil 2012: 17). Therefore, it is clear that the development-defense nexus, as reflected in Brazil's security policy, is tied to and passes through the South Atlantic. Therefore, promoting a conflict-free zone in the region, either by diplomatic means or via military co-operation, is key to Brazilian development.

In 2013, the PND was revised in order to convey the 'planning of actions destined towards national defence co-ordinated by the Ministry of Defence' (Ministry of Defence of Brazil 2013: 1) On the South Atlantic issue, the document reiterates important points of the END and the White Paper, and reinforces the notion of a development-defence nexus (Ministry of Defence of Brazil 2013: 1). In addition, it clearly links the country's development to trade via sea routes and the extraction of living and non-living resources from the sea, further confirming the central importance of the maritime region.

The revised PND makes it clear that the defence of Brazil's national territory extends to the other side of the South Atlantic (Ministry of Defence of Brazil 2013: 8). This creates a need to build a South Atlantic identity that establishes a Brazilian presence in the entire region, from the east side of South America to the west side of Africa. In this perspective, the PND makes it clear that the area of influence of its security policy extends beyond South America, including the South Atlantic as well as African countries on the other side of the Atlantic (Ministry of Defence of Brazil 2013: 4).

The document spells out strategies for mitigating the potential for conflict in this strategic environment. These include the intensification of co-operation and trade with African countries; the consolidation of the ZPCSA and South Atlantic co-operation; and continued dialogue about interregional interaction, like the Africa-South America Summit and the India-Brazil-South Africa Dialogue Forum (Ministry of Defence of Brazil 2013: 4).

Abdenur and Souza Neto (2014: 6) point out the growing articulation between Brazilian foreign and defence policy, and that South-South co-operation creates the conditions for narrowing both policies. They further highlight its role as a tool for building a common South Atlantic identity, presented as a safe way for Brazil to pursue its strategic interests. In this regard, the initiatives spelled out in the END, White Paper and PND corroborate the construction of an identity of the South Atlantic which seeks to contribute to regional stability and the avoidance of conflicts in the region, thereby providing a platform for development (Abdenur and Marcondes Neto 2014: 5). 


\section{Naval co-operation}

Among the areas of co-operation, naval initiatives deserve particular emphasis. Besides logistic support with the acquisition of equipment and shipping, they embrace the promotion of joint military action, the transfer of knowledge and experience, and research and development. These goals are pursued via exchanges of officials and instructors, visits by delegations, courses, seminars, cultural events, and even commercial trade (Aguilar 2013).

Multiple co-operation initiatives in a sensitive area such as defence suggest the existence of mutual trust and friendly relations among states. Given its strategic goal of creating a South Atlantic RSC, and warding off external threats, Brazil has been trying to expand its partnerships. Since 1990, marine co-operation programmes have been undertaken with Cape Verde, Nigeria, Angola, Senegal, Guinea and South Africa. These have complemented continued naval simulation exercises with Argentina and Uruguay aimed at protecting commercial trade routes in the South Atlantic region (Aguilar 2010). In 1994, Brazil signed its first relevant co-operation agreement after its period of military government with Namibia. Significantly, the agreement was entered into by the Brazilian Navy and the Namibian Ministry of Defence, rather than their foreign ministries. The synergy between foreign policy and defence policy which developed under the Lula administration had not yet begun.

The construction of a South Atlantic identity involves the notion of threats from outside, and the need for the countries in the region to address common interests and concerns. Brazil has aimed to start this process, seeking to create conditions for increasing its own influence in the region (Abdenur and Souza Neto 2014: 6, 7).

Brazil is working to limit the activities of what it terms 'extra-regional powers' (such as the permanent members of the UN Security Council, and even as Turkey and Iran) and to counter threats such as piracy, and drug and human trafficking through a regional security strategy. Given the increase in piracy in the Gulf of Guinea, Brazil has reinforced co-operation in the military field, aiming to enable the naval forces of coastal states to conduct joint naval patrolling and defence exercises. The region is responsible for the extraction of 5.4 million barrels of oil a day, and the ocean is the main route of exportation (Chatham House 2013). Attacks on this area would threaten important trade routes, which has provoked the concerns of extra-regional powers such as the five permanent members of the UN Security Council. The desire to confront these illegal practices is not only justified by economic and strategic concerns, but also by possible links with terrorist groups. In seeking to address this threat, the USA has been conducting joint naval training exercises popularly called the 'Obangame Express', in partnership with African and European countries. Brazil participated in these exercises for the first time in 2014 (DefesaNet 2014).

Seeking to guarantee its leadership role in the South Atlantic and counter global powers' attempts to penetrate the region, Brazil also conducted anti-piracy training in partnership with South Atlantic states in 2012 and 2013. In 2014, it created a Navy mission centre in São Tomé and Príncipe tasked with identifying the needs of navies in the region and creating more assertive bilateral co-operation initiatives (Portal Brazil 2014). In February 2015, the Brazilian Navy hosted the president of the Inter-Regional Coordination Centre 
for Maritime Security in the Gulf of Guinea, and the advisor to Cameroon on defence and security issues. At the time, the delegation engaged with the vigilance system used by the Brazilian $\mathrm{Navy}^{5}$ (Poder Naval 2015).

Extensive military co-operation with São Tomé, Namibia and Cape Verde, among others, attest to Brazil's regional intentions, as well as its increased military capacity for the protection of the maritime commercial routes and its offshore oil assets. These politics allow for increased interaction among states and the strengthening of ties among them, leading to an expansion of Brazilian influence and support for its strategic priorities (Abdenur and Souza Neto 2014b).

As Abdenur and Souza Neto (2014b) argue, Brazilian efforts to create a South Atlantic consciousness also serve to justify it pledge to expand its continental platform under UNCLOS. In this regard, Brazil has given support to Angola and Namibia (Ministry of Defence of Brazil 2013), helping them to strengthen and combine their continental platforms (Abdenur and Souza Neto 2014b). If these pledges are approved, these states will have exclusive rights to exploit the natural resources located in the areas in question. Therefore, these shared continental platforms are strengthening the Brazilian interest in avoiding the intrusion of extra-regional powers (Ribeiro Luis 2001).

Today, Brazil is also involved in a range of security and defence projects with Angola, São Tomé and Príncipe, Mozambique, South Africa, Nigeria and Senegal. They cover a broad range of activities, including the purchase of ships and equipment, the training of troops, and the organisation of local navies. All these countries except for Mozambique are part of the ZPCSA, an instrument that, as we already mentioned, was created within the ambit of foreign policy and defence policy and regarded as fundamental to the development of a South Atlantic identity. No wonder, then, that Brazil has stepped up military co-operation with these countries. It should also be recalled that, while Mozambique is not a member of the ZPCSA, it is part of the Community of Portuguese Language Countries (PALOPS), which was also a focus of Brazilian foreign policy under Lula's administration.

At this point, is important to note the relevance of cultural and linguistic ties and a common colonial history, and how they benefit the creation of a shared consciousness among Brazil and African Portuguese-speaking countries, considering that almost all of them are located in the South Atlantic region, and all of them are receivers of a major parcel of Brazilian development assistance. The special status given to African Portuguesespeaking states is evident in official documents such as the PND, which notes: 'Brazil attributes priority to the countries of South America and Africa, especially Western African and Lusophone states, seeking to deepen its ties to these countries' (Ministry of Defence of Brazil 2013: 6).

Therefore, the Portuguese language has become an important instrument for consolidating and extending Brazilian influence in the region. For example, training offered by the Brazilian Navy to West African countries has been provided in Portuguese, even for officers from non-Portuguese-speaking countries, and include a one-year adaptation 
period during which officers study the Portuguese language and subjects such as physics and calculus (BBC Brasil 2013).

Among PALOPS members, Angola has been one of the main recipients of Brazilian co-operation. As stated by the Angolan minister of defence, João Manuel Gonçalves, sharing a language and common points of view allow the creation of solid co-operation ties between the two states (Ministry of Defence of Brazil 2014). Brazil was the first country to recognise Angolan independence in 1975, and the historical co-operation between these two countries started in 1980, when co-operation agreements were signed in numerous areas. Angola is considered a strategic partner since it is the closest southern African country to Brazil. During the governments of Luiz Inácio Lula da Silva and José Eduardo dos Santos, Brazil and Angola created a strategic partnership in 22 areas (ABC n.d.), and in 2014, the two countries launched a programme for the empowerment of the Angolan Navy, entitled PRONAVAL. Unfortunately, implementation of this and other programmes has been hamstrung by the current financial and political crisis in Brazil.

\section{A South Atlantic RSC?: final remarks}

We have tried to demonstrate that, as Brazil's strategic interest in the South Atlantic region - always present in the country's debates on strategic policy - has been rekindled by elements such as the discovery of vast oil reserves; a swing towards investment in the African content during the Lula presidency; and the perceived increased vulnerability of ever-important trade routes to outside powers, Brazil has responded not only in material terms but also with initiatives in the ideational realm. Prominent among the latter has been the fostering of a common identity among both African and South American states bordering the South Atlantic Ocean, providing evidence of the emergence of a security complex in the area.

Some 15 years ago, Buzan and Wæver (2003: 322-3) pointed to a Southern Cone region as a subregional security complex on the verge of becoming a security community, considering the rapprochement between Brazil and Argentina and the advance of regional integration through Mercosur. They highlighted growing co-operation in the economic and nuclear arenas and the redefinition of geopolitical thinking which helped to change the pattern of interaction between them, resulting in a structural change in this subcomplex (Buzan and Wæver 2003: 317).

Considering Buzan and Wæver's conception of a RSC as a region where the securitisation and desecuritisation processes cannot be analysed separately from one another, we argue that, via the abovementioned initiatives, Brazil is expanding its linkages and influence not only in South America but also among South Atlantic states, thereby contributing to creating a South Atlantic RSC. As highlighted by Arie Kacowicz (1998: 13), the South American and West African regions are characterised by the absence of interstate conflicts and a negative peace, despite their domestic instabilities.

Regarding the three criteria proposed by Buzan and Wæver for classifying RSCs (patterns of interaction, polarities, and the roles of members in the international system), it can be argued that, given the low probability of conflict among its members, the institu- 
tionalisation of the region through the restoration of the ZPCSA, and recurrent regional co-operation initiatives, the South Atlantic RSC is characterised by amicable relations among its constituents. Given the importance and leadership roles of Brazil as well South Africa, it also assumes a multipolar configuration Both these countries are also partners in institutionalised co-operation initiatives such as BRICS and IBSA, and can be seen as important interlocutors of the global South in multilateral forums.

Finally, given its members' roles in the international system, it is possible to affirm that the South Atlantic RSC is a standard one, as none of its actors can be seen as a superpower. However, the strategic importance of this region and its valuable resources make it susceptible to great power interference, such as the resurrection of the US Navy's Fourth Fleet and increased Chinese militarisation of its interaction with the region. In line with this, Brazil has pointed out the existence of common values and threats to states in the region, and contributed to a desecuritisation process in the South Atlantic. Therefore, it is possible to affirm that Brazil is seeking to build a security community through the strengthening of co-operation in multiple arenas, and through attempts to produce a common understanding of its actors' interests and values.

The various co-operation initiatives among Brazil and the other South Atlantic states in the sensitive military area reveal the existence of relationships of mutual trust, which cannot be analysed only in material terms. This creates an opportunity for changing the views and perceptions of the various South Atlantic states, which, in turn, creates the conditions for the birth of a common South Atlantic identity. This does not mean that all South Atlantic actors already share this common consciousness - even if the elites and governmental actors agree with the existence of a South Atlantic identity, it is not shared by the majority of their societies (Oelsner 2016: 175). On the contrary, the point we wish to stress is that Brazil is trying to build a regional identity through discourses that emphasise a common history, language and interests, and through co-operation initiatives that are justified via the construction of common threats. The result is that the Brazilian strategy to keep the region free of penetration has helped to turn the South Atlantic into an RSC with some characteristics of a security community, even if a very loose one.

\section{Notes}

1 The ZPCSA was established in 1986 by UN General Assembly Resolution 41/11. It consists of 24 countries bordering the South Atlantic, namely South Africa, Angola, Argentina, Benin, Brazil, Cape Verde, Cameroon, Congo, Ivory Coast, Gabon, Gambia, Ghana, Guinea, Guinea-Bissau, Guinea-Equatorial, Liberia, Namibia, Nigeria, Democratic Republic of Congo, Sao Tome and Principe, Senegal, Sierra Leone, Togo and Uruguay.

2 The so-called pre-salt layer is a part of the subsoil under the sea that lies under a layer of salt, containing a huge reservoir of oil and natural gas. It is located mainly in the basins of Santos (SP), Campos (RJ) and Espírito Santo (ES). The potential of the pre-salt reserves is between 28 and 35 billion barrels of oil.

3 Coined in 2004 in a newspaper article by the then-Commandant of the Brazilian Navy, Roberto Guimarães Carvalho, the term evokes the importance of the terrestrial Amazon region in Brazilian strategic thinking. It comprises the country's Economic Exclusion Zone (EEZ) and several areas pertaining to the continental platform.

4 Unless otherwise noted, all translations from Portuguese into English are free, and done by the authors. 
5 This system is meant to provide the Brazilian armed forces with the means to exercise surveillance, control and defence over Brazilian territory, territorial waters, and Brazilian airspace, including continental and maritime areas. This includes maintaining the security of sea and air communication and navigation, especially in the South Atlantic.

\section{References}

Abdenur, Adriana and Danilo Marcondes de Souza Neto. 2014a. 'O Atlântico Sul e a Cooperação em Defesa entre o Brasil e a África'. In Reginaldo Nasser and Rodrigo Moraes (eds), O Brasil e a Segurança em seu entorno regional. Brasília: Instituto de Pesquisa Econômica e Aplicada.

. 2014b. 'O Brasil e a Cooperação em Defesa: a construção de uma identidade regional no Atlântico Sul.' Revista Brasileira de Política Internacional, 57 (1): 5-21.

2015. 'La creciente influencia de China en el Atlántico Sur'. In Sebastián Mantilla Baca (ed), La expansión de China en América Latina. Quito: Centro Latinoamericano de Estudios Políticos (CELAEP)/Fundación Hanns Seidel.

Acharya, Amitav. 2009. Constructing a Security Community in Southeast Asia: ASEAN and the Problem of Regional Order. London: Routledge.

Acioly, Luciana and Rodrigo Moraes (eds). 2011. Prospectiva, estratégias e cenários globais: visões de Atlântico Sul, África Lusófona, América do Sul e Amazônia. Brasília: Instituto de Pesquisa Econômica e Aplicada.

Aguilar, Sérgio Luiz. 2010. Segurança e Defesa no Cone Sul: da rivalidade da Guerra Fria à cooperação atual. São Paulo: Porto de Ideias.

2013. 'Atlântico Sul: as relações do Brasil com os países africanos no campo da segurança e defesa'. Austral Revista Brasileira de Estratégia e Relações Internacionais. 2(4): 49-71.

Almeida Silva, Antonio Ruy de. 2014. 'O Atlântico Sul na Perspectiva da Segurança e da Defesa'. In Reginaldo Mattar Nasser and Rodrigo Fracalossi de Moraes (eds), O Brasil e a segurança no seu entorno estratégico: América do Sul e Atlântico Sul. Brasília: Instituto de Política Econômica Aplicada.

BBC Brasil. 2013. 'No Brasil, africanos buscam formação militar e enfrentam saudade de casa'. 16 May. At: http//www.bbc.com/portuguese/noticias/2013/05/130516_africanos_escolanaval_cq. [accessed on 1 January 2017].

Brazilian Cooperation Agency (ABC). n.d. Online. At: http://www.abc.gov.br/Projetos/CooperacaoSulSul/Angola [accessed on 1 January 2017].

Buzan, Barry. 1991. People, States and Fear: An agenda for international security studies in the PostCold War era. New York: Harvester Wheatsheaf.

Buzan, Barry and Ole Wæver. 2003. Regions and Powers: the Structure of International Security. Cambridge: Cambridge University Press.

Chatham House. 2013. Maritime Security in the Gulf of Guinea: Report of the conference held at Chatham House, London. At: https://www.chathamhouse.org/sites/files/chathamhouse/public/Research/Africa/0312 confreport_maritimesecurity.pdf [accessed on 1 January 2017]

Defesanet. 2014. 'APA' participa do 'Obangame Express 2014'. At: http://www.defesanet.com.br/na$\mathrm{val} /$ noticia/15630/NPaOc- \%E2\%80\%9CAPA\%E2\%80\%9D-participa-do-\%E2\%80\%9CObangameExpress-2014\%E2\%80\%9D [accessed on 1 January 2017] 
Frazier, Derrick and Robert Stewart-Ingersoll. 2010. 'Regional Powers and Security: A framework for understanding order within regional security complexes.' European Journal of International Relations 16 (4): 731-753.

IBGE (Brazilian Institute of Geography and Statistics). 2011. Atlas Geográfico das Zonas Costeiras e Oceânicas. At: http://biblioteca.ibge.gov.br/visualizacao/livros/liv55263.pdf [accessed on 1 January 2017].

Jobim, Nelson. 2010. Speech during the final session of the International Conference 'O Futuro da Comunidade Transatlântica'. 10 September.

Kacowicz, Arie M. 1998. Zones of Peace in the Third World: South America and West Africa in Comparative Perspective. Albany: State University of New York Press.

Ministry of Defence of Brazil. 2012. Política Nacional de Defesa. At: http://www.defesa.gov.br/arquivos/estado_e_defesa/END-PND_Optimized.pdf [accessed on 1 January 2017].

. 2013. 'Ministro da Defesa viaja à África para ampliar cooperação com Angola e Namíbia'.

17 February. At: http://www.defesa.gov.br/noticias/4226-17-02-2013-defesa-ministro-da-defesaviajaa-africa-para-ampliar-cooperacao-com-angola-e-namibia> [accessed on 1 January 2017].

2014. 'Angola busca cooperação brasileira para implementar Programa Naval'. 5 August. At: http://www.defesa.gov.br/index.php/noticias/13329-angola-busca-cooperacaobrasileira-paraimplementar-programa-naval [accessed on 1 January 2017].

Ministry of Foreign Affairs of Brazil. 2013a. 'Nota Informativa n. 2: combate à pirataria e aos ilícitos marítimos no Golfo da Guiné. June. At: http://www.itamaraty.gov.br/index.php?option=com_ content\&view=article\&id=3508: combate-a-pirataria-e-aos-ilicitos-maritimos-no-golfo-da-guine $\&$ catid=42\&lang=ptBR\&Itemid $=280$ [accessed on 1 January 2017].

. 2013b. 'Texto Base do Discurso do Ministro Antônio de Aguiar Patriota por ocasião da VII Reunião Ministerial da Zona de Paz e Cooperação do Atlântico Sul'. At: http://www.itamaraty.gov. br/index.php?option=com_content\&view=article\&id=4547: vii-reuniao-ministerial-da-zona-depaz-e-cooperacao-do-atlantico-sul-ZPCSAtexto-base-do-discurso-do-ministro-antonio-de-aguiar-patriota-montevideu-15-dejaneiro-de-2013\&catid=194\&Itemid=454\&lang=pt-BR [accessed on 1 January 2017].

Oelsner, Andrea. 2016. 'Pluralistic Security Communities in Latin America' In David R Mares and Arie M Kacowicz (eds). Routledge Handbook of Latin American Security. Routledge: New York.

Paim, Maria Augusta. 2014. 'A Expansão da Amazônia Azul: A Plataforma Continental do Brasil Além das 200 Milhas Náuticas'. In André Panno Beirão and Antônio Celso Alves Pereira (eds), Reflexões sobre a Convenção do Direito do Mar’. Brasília: Fundação Alexandre Gusmão.

Penna Filho, Pio. 2003. 'Regionalismo, Segurança e Cooperação: o Atlântico Sul como Espaço de Possibilidades entre o Cone Sul e a África Austral'. Paper presented at XXVII Encontro Anual da Associação Nacional de Pós-Graduação e Pesquisa em Ciências Sociais (ANPOCS). Caxambu. October.

2015. 'Reflexões sobre o Brasil e os Desafios do Atlântico Sul no início do Século XXI'. In Gilberto Fernando Gheller, Selma Lúcia de Moura Gonzales and Laerte Peotta de Mello (eds), Amazônia e Atlântico Sul: desafios e perspectivas para a defesa no Brasil. Brasília: Instituto de Pesquisa Econômica Aplicada. 
Poder Naval. 2015. 'Pirataria no Golfo da Guiné mantém marinhas africanas atreladas ao apoio do Brasil'. 24 February. At: http://www.naval.com.br/blog/2015/02/24/pirataria-no-golfo-da-guinemantemmarinhas-africanas-atreladas-ao-apoio-do-brasil/ [accessed on 1 January 2017].

Portal Brasil. 2014. 'Brasil cria núcleo de missão naval em São Tomé e Príncipe'. 11 November. At: http://www.brasil.gov.br/defesa-eseguranca/2014/11/brasil-cria-nucleo-de-missao-naval-em-saotome-e-principe [accessed on 1 January 2017].

Presidency of Brazil. 2008. Estratégia Nacional de Defesa. At: http://www.defesa.gov.br/projetosweb/ estrategia/arquivos/estrategia_defesa_nacional_portugues.pdf [accessed on 10 January 2016].

. 2012. Livro Branco de Defesa Nacional. At: http://www.defesa.gov.br/arquivos/2012/mes07/ lbdn.pdf [accessed on 1 January 2017].

Ribeiro Luis, Camila Cristina. 2011. 'Cooperação para a paz e segurança regional: o Brasil e o Atlântico Sul'. Paper presented at III Simpósio de Pós-Graduação em Relações Internacionais do Programa San Tiago Dantas. November.

Silva, Alexandre Pereira da. 2013. 'O novo pleito brasileiro no mar: a plataforma continental estendida e o Projeto Amazônia Azul'. Revista Brasileira de Polítivca Internacional 56(1): 104-121.

Varella Neves, André Luiz. 2015. 'Atlântico Sul: Projeção Estratégica do Brasil para o Século XXI'. In Gilberto Fernando Gheller, Selma Lúcia de Moura Gonzales, Laerte Peotta de Mello (eds.) Amazônia e Atlântico Sul: desafios e perspectivas para a defesa no Brasil. Brasília: Instituto de Pesquisa Econômica Aplicada.

\section{About the authors}

Beatriz Rodrigues Bessa Mattos is Substitute Professor in the Department of Defence and International Strategic Management of the Federal University of Rio de Janeiro (DGEI/ UFRJ), Brazil. She is also a PhD candidate in International Relations at IRI/PUC-Rio, and an assistant researcher at the BRICS Centre for Studies and Research (BRICS Policy Centre). She holds an MA in International Relations and Political Science from the University Research Institute of Rio de Janeiro, part of Candido Mendes University (IUPERJ/ UCAM), Brazil. She is currently engaged in research on the connections between climate change and international security studies, environmental security, and the international climate regime.

Francisco Eduardo Lemos de Matos is a PhD student in International Relations at IRI/ PUC-Rio. He holds an MA in Political Science from the Fluminense Federal University (UFF), a specialisation certificate in the History of International Relations from the State University of Rio de Janeiro (UERJ), and a BA in International Relations from Estácio de Sá University (UNESA), Brazil. He is a member of the Brazilian Association of International Relations (ABRI) and the International Studies Association (ISA). His main areas of interest are the theory of international relations, and post-colonial studies. He is currently engaged in research about the limits of land and sea, and the limits of liberty and freedom in relation to sovereignty. 
Kai Michael Kenkel is Associate Professor at the Institute of International Relations at the Pontifical University of Rio de Janeiro (IRI/PUC-Rio), Brazil, and Associate Researcher at the German Institute of Global and Area Studies in Hamburg. He holds PhD and MA degrees from the Graduate Institute (then IUHEI) in Geneva and a BA from The Johns Hopkins University (USA). He has published extensively on security issues, including humanitarian intervention and the responsibility to protect, and on Brazil's role in UN peace operations. He was Editor-in-Chief of Contexto Internacional from 2011 to 2013, and has recently served on the board of the Brazilian Defence Studies Association. He is the Coordinator-General of the project entitled 'Brazil and Security in the South Atlantic', which forms the basis for this special issue.

Received on 22 June 2016, and approved for publication on 4 January 2017.

\section{(cc) BY-NC} https://creativecommons.org/licenses/by-nc/4.0/ 